\title{
Correlations chart: Tool to analyse the dynamics of water quality parameters
}

\author{
Cézar H. B. Rocha ${ }^{1}$, Antoine P. Casquin ${ }^{2}$ \& Renata O. Pereira ${ }^{3}$
}

\footnotetext{
${ }^{1}$ Universidade Federal de Juiz de Fora/Faculdade de Engenharia/Núcleo de Análise Geo Ambiental. Juiz de Fora, MG, Brasil. E-mail: barra.rocha@gmail.com (Corresponding author) - ORCID: 0000-0003-1321-158X

${ }^{2}$ Universidade Federal de Juiz de Fora/Instituto de Ciências Biológicas/Programa de Pós-Graduação em Ecologia. Juiz de Fora, MG, Brasil. E-mail: a.casquin@gmail.com - ORCID: 0000-0001-6897-0183

${ }^{3}$ Universidade Federal de Juiz de Fora/Faculdade de Engenharia/Programa de Pós-Graduação em Ambiente Construído. Juiz de Fora, MG, Brasil. E-mail: renata.pereira@uff.edu.br - ORCID: 0000-0002-3414-7292
}

\begin{abstract}
The search for statistical techniques and forms of graphical representation that can explain the most relevant correlations among limnological variables can help interpret phenomena in a body of water. The objective of the article was to propose a graphical representation of the correlations among limnological variables applied in the contributing basin of the Dr. João Penido reservoir, in Juiz de Fora, Minas Gerais state, Brazil. Six sections were monitored monthly from May 2012 to April 2014, analysing 15 water quality parameters and their statistical correlations. The correlations were represented graphically with the program Gephi 0.8.2-beta. The influence of organic matter (of natural and anthropogenic origin resulting from pasture runoff and sewage) on water quality was verified, with an observed increase in water quality parameters especially nitrogen and phosphorous, oxygen consumed, chemical oxygen demand, turbidity and total suspended solids. It is concluded that the correlation chart assists in the understanding of the dynamics of the water quality parameters at the different sites analysed.
\end{abstract}

Key words: water resources, limnological variables, hydrographic basin

\section{Gráfico de correlações: Ferramenta para análise da dinâmica de parâmetros de qualidade da água}

RESUMO: A busca de técnicas estatísticas e/ou formas de representação gráfica que consigam explicar as correlações mais relevantes entre as variáveis limnológicas podem auxiliar na interpretação dos fenômenos atuantes naquele corpo d'água. $\mathrm{O}$ objetivo do artigo é propor uma representação gráfica das correlações entre variáveis limnológicas aplicada na bacia de contribuição da represa Dr. João Penido, em Juiz de Fora, Minas Gerais, Brasil. Foram monitoradas seis seções mensalmente de maio de 2012 a abril de 2014, sendo analisados quinze parâmetros de qualidade da água e estes correlacionados estatisticamente. As correlações foram então representadas graficamente através do Programa Gephi 0.8.2-beta. Verificou-se a influência da matéria orgânica na qualidade da água, de origem natural e antrópica, oriundos de escoamento superficial das pastagens e do esgoto doméstico, observando uma piora nos parâmetros de qualidade da água com destaque para o nitrogênio e fósforo, oxigênio consumido, demanda química de oxigênio, turbidez e sólidos suspensos totais. Conclui-se que o gráfico de correlação auxilia no entendimento da dinâmica entre os parâmetros de qualidade da água do local analisado.

Palavras-chave: recursos hídricos, variáveis limnológicas, bacia hidrográfica 


\section{INTRODUCTION}

The quality of water resources has deteriorated in many places due to natural and anthropogenic factors. In the southeastern region of Brazil, water supply systems generally make use of the catchment in artificial reservoirs. Therefore, the contributing basin has become a unit of analysis to investigate and understand the processes of water resources.

The contributing basin of the Dr. João Penido reservoir (CBJPR) - Juiz de Fora, Minas Gerais state, Brazil, has been under great anthropogenic pressure because of its proximity to the city $(10 \mathrm{~km})$. It has the last unoccupied flat areas in the region, as well as the recent construction of State Highway AMG-3085. There is also an urban development connected to leisure activities, in addition to farms and gated communities at the edges of the reservoir.

According to Vasco et al. (2011), it is necessary to study urban and rural hydrographic basins to balance the exploitation of natural resources and environmental vulnerability. These areas are often occupied in a disorderly fashion in Brazil (Bailly et al., 2012; Moraes et al., 2014); however, it is necessary to mitigate these problems.

There are various methods to evaluate and analyse water quality. Among these are monitoring physico-chemical and biological parameters, in addition to biological indicators that are recommended and may complement the interpretation of the results (WFD, 2000). In analysing and interpreting the results, simpler analyses such as the Framework Conformity
Index (CCME, 2001) was used; Water Quality Index (Bucci \& Oliveira, 2014); boxplot graphs (Rocha et al., 2016); in addition to more complex analyses such as multivariate analysis and correlation tables (Bu et al., 2014; Azhar et al., 2015; Bucci et al., 2015; Rocha \& Pereira, 2016; Trindade et al., 2017), which have higher complexity for interpretation.

The objective of this work was to propose a tool to help graphically evaluate the correlations between limnological variables in impacted areas, using CBJPR as a case study.

\section{Material ANd Methods}

The Dr. João Penido reservoir catchment is located at $21^{\circ}$ $41^{\prime} 3.3^{\prime \prime} \mathrm{S}$ and $43^{\circ} 24^{\prime} 12.68^{\prime \prime} \mathrm{W}$ (Datum SIRGAS 2000). It has a contributing basin of $59.48 \mathrm{~km}^{2}$ and the longest tributary is $6.12 \mathrm{~km}$ (Figure 1). The water surface has an area of $3.7 \mathrm{~km}^{2}$ and a mean depth of $6.53 \mathrm{~m}$ (CESAMA, 2014).

The software ESRI ${ }^{\circledR}$ ArcMap $^{\text {TM }}$ 10.2.1 was used to create the map of land use and cover of the CBJPR using Landsat 8 imagery from August 1, 2013, aiming to coincide with the field collection period.

Six sections with different characteristics were selected for monitoring, labeled: P1 - Spring in the Atlantic Forest; P2 Culvert in the mean course of the principal tributary under the road adjacent to the rural area; P3 - Culvert under State Highway AMG-3085 in the grazing area of the Burros stream in the reservoir; P4 - Culvert under Highway AMG-3085 in

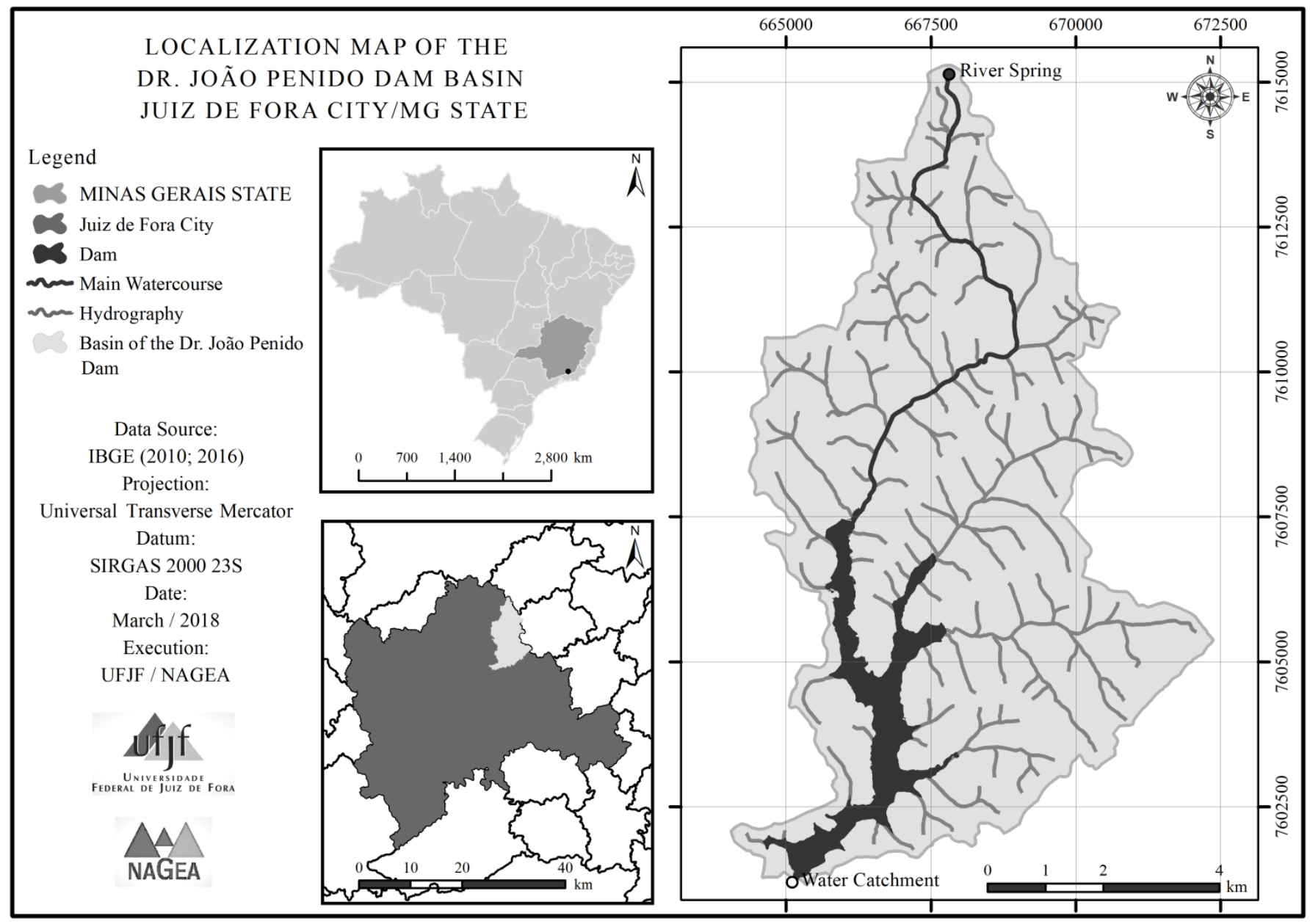

Figure 1. Map of the location of the CBJPR in Juiz de Fora, Minas Gerais State, Brazil 
pasture area of the Grama stream; P5 - Outlet of the Vista Alegre stream in the rural area; and P6 - Catchment to the Water Treatment Station (Figure 2).

Table 1 presents the descriptions of each class in the subbasins at the monitored sites.

Samples were collected once per month at the six points established, from May 2012 to April 2014, which included two hydrologic cycles. The correlations between the variables are discussed based on the literature and land use and cover in the subbasins and margins as shown in Figure 2.

The water quality parameters analysed were: $\mathrm{pH}$, turbidityTur (NTU), total suspended solids -TSS $\left(\mathrm{mg} \mathrm{L}^{-1}\right)$, electrical
Table 1. Definitions of the land use classes in the subbasins of the Dr. João Penido reservoir (CBJPR)

\begin{tabular}{ll}
\hline \multicolumn{1}{c}{ Classes } & \multicolumn{1}{c}{ Description } \\
Forest & $\begin{array}{l}\text { Class referring to plant physiognomy of the Atlantic } \\
\text { Forest }\end{array}$ \\
Wetland & $\begin{array}{l}\text { Area covered principally by Typha sp. } \\
\text { Includes the roads and areas with land reclaimed for } \\
\text { the provision of buildings and the buildings } \\
\text { themselves }\end{array}$ \\
Urban area & $\begin{array}{l}\text { Refers to areas subject to the water storage due to } \\
\text { the dam }\end{array}$ \\
Reservoir & $\begin{array}{l}\text { Areas where pasture is degraded by fire, overgrazing } \\
\text { or erosion }\end{array}$ \\
Degraded Pasture & Undergrowth vegetation used by livestock \\
\hline Pasture &
\end{tabular}

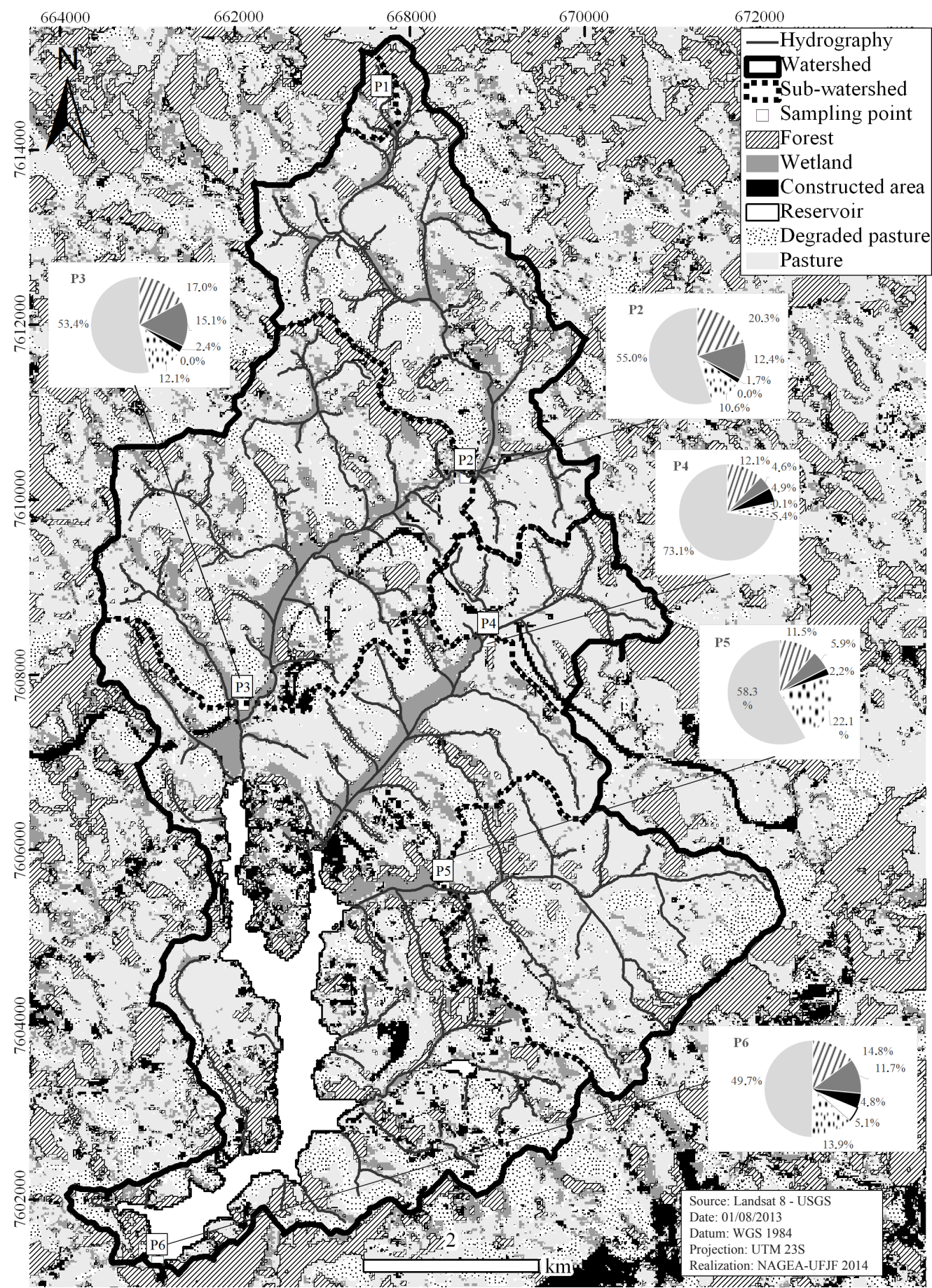

P1 - Spring in the Atlantic Forest; P2 - Culvert in the mean course of the principal tributary under the road adjacent to the rural area; P3 - Culvert under State Highway AMG-3085 in the grazing area of the Burros stream in the reservoir; P4 - Culvert under Highway AMG-3085 in pasture area of the Grama stream; P5 - Outlet of the Vista Alegre stream in the rural area and P6 - Catchment to the Water Treatment Station

Figure 2. Map of land use and cover at the Dr. João Penido reservoir (CBJPR), with the monitored sites highlighted 
conductivity-Cond $\left(\mu \mathrm{Cm}^{-1}\right)$, dissolved oxygen-DO $\left(\mathrm{mg} \mathrm{L}^{-1}\right)$, oxygen consumed-OC $\left(\mathrm{mg} \mathrm{L}^{-1}\right)$, chemical oxygen demand$\mathrm{COD}\left(\mathrm{mg} \mathrm{L}^{-1}\right)$, biochemical oxygen demand-BOD ${ }_{5.20}\left(\mathrm{mg} \mathrm{L}^{-1}\right)$, ammonium- $\mathrm{NH}_{4}^{+}\left(\mu \mathrm{g} \mathrm{L}^{-1}\right)$, nitrite- $\mathrm{NO}_{2}^{-}\left(\mu \mathrm{g} \mathrm{L}^{-1}\right)$, nitrate$\mathrm{NO}_{3}^{-}\left(\mu \mathrm{g} \mathrm{L}^{-1}\right)$, total nitrogen-TN $\left(\mu \mathrm{g} \mathrm{L}^{-1}\right)$, dissolved inorganic phosphate- $\mathrm{PO}_{4}^{3-}\left(\mu \mathrm{g} \mathrm{L}^{-1}\right)$, total phosphorous-TP $\left(\mu \mathrm{g} \mathrm{L}^{-1}\right)$ and Escherichia coli-E.coli (NMP $100 \mathrm{~mL}^{-1}$ ). The procedure for collecting samples followed the National Guide for Collecting and Preserving Samples (ANA, 2011). The parameters pH, Cond and DO were determined at the sites with a Hanna Multiparameter Probe model HI-9828. The other parameters were $\mathrm{BOD}_{5.20}$ - respirometry; $\mathrm{OC}$ - oxidation by permanganate in acidic media (Macedo, 2005); COD - oxidation by dichromate; nutrients - spectrometry; turbidity - Hanna turbidity meter model HI 93703; and E.coli - membrane filter (APHA, 2012).

For each monitoring site the Pearson correlation matrix was calculated among the parameters, as well as the p-value matrices (significance) with the software SPSS ${ }^{\bullet} 15.0$. The correlations were analysed at two significance levels, with 0.05 and 0.01 , and were tabulated in the software Microsoft Excel 2010 and imported into the network graphing program Gephi 0.8.2-beta.

To make the correlation charts, it was considered that the visualization originated from a principle: the "nodes" are the variables and the edges are the correlations. The algorithm that generated the chart, Force Atlas 2, works on a simple principle: the connected nodes attract and non-connected nodes repulse (Jacomy et al., 2014), producing more intelligible charts with fewer interpretation conflicts (Kobourov, 2012) when comparing with the tables of correlation frequently used. The graphical analysis allows to have a new look about the biogeochemical phenomena that occur in freshwater, complementing other approaches.

The size of the node depends on the number of correlations of the variable. The visualization of "correlation charts" is an original proposal of the authors, which along with the correlation tables shows key parameters as well as the functions of the land use and cover conditions in the subbasin and in the vicinity of the point and assists to understand the parameter dynamics in the monitored section.

\section{Results AND Discussion}

Table 2 presents the correlation matrices commonly used to demonstrate the results.

Figure 3 presents the correlations with 0.05 and 0.01 significance among the water quality parameters analyzed.

The significant positive correlations were represented by continuous lines and the negative correlations by dashed lines. The correlations with significance between 0.01 and 0.05 were symbolized by a thin line and those with 0.01 by a thicker line. All variables were analyzed at all sampled points. Variables not shown on the chart did not have significant correlation with the other parameters analyzed.

At P1, spring of the Vargem Grande stream, the variables studied presented lower correlation than at the other points, with TN being a key parameter of the site dynamics (Figure $3 \mathrm{~A})$. Due to characteristics of the spring environment, a preserved Atlantic Forest fragment, the TN input originated

Table 2. Correlation matrices among the parameters of water quality

\begin{tabular}{|c|c|c|c|c|c|c|c|c|c|c|c|c|c|c|}
\hline & $\mathrm{pH}$ & TSS & Cond & Tur & DO & OC & COD & BOD & $\mathrm{NH}_{4}$ & $\mathrm{NO}_{2}$ & $\mathrm{NO}_{3}$ & TN & $\mathrm{PO}_{4}$ & TP \\
\hline & & & & & & & P1 & & & & & & & \\
\hline TSS & 0.36 & & & & & & & & & & & & & \\
\hline Cond & $0.59^{\star \star *}$ & -0.14 & & & & & & & & & & & & \\
\hline Tur & -0.16 & -0.2 & -0.13 & & & & & & & & & & & \\
\hline D0 & 0.02 & -0.03 & -0.1 & 0.26 & & & & & & & & & & \\
\hline$O C$ & 0.38 & -0.13 & $0.56^{\star *}$ & -0.11 & -0.03 & & & & & & & & & \\
\hline COD & -0.36 & -0.16 & -0.19 & 0 & -0.08 & -0.06 & & & & & & & & \\
\hline BOD & -0.36 & 0.06 & -0.25 & -0.13 & -0.08 & -0.18 & 0.19 & & & & & & & \\
\hline $\mathrm{NH}_{4}$ & 0.17 & 0.02 & 0.22 & -0.05 & -0.11 & 0.31 & 0.05 & -0.04 & & & & & & \\
\hline $\mathrm{NO}_{2}$ & -0.23 & 0.06 & -0.22 & -0.03 & -0.33 & -0.1 & 0.12 & 0.04 & 0.38 & & & & & \\
\hline $\mathrm{NO}_{3}$ & 0.3 & -0.06 & 0.27 & 0.2 & 0.23 & 0.22 & -0.16 & -0.36 & $0.51^{\star \star}$ & 0.36 & & & & \\
\hline TN & $0.44^{*}$ & -0.14 & $0.66^{\star *}$ & 0.01 & 0.12 & $0.51^{* *}$ & -0.23 & -0.34 & $0.47^{*}$ & 0.09 & $0.83^{* *}$ & & & \\
\hline $\mathrm{PO}_{4}$ & 0.25 & 0.08 & 0.07 & -0.19 & -0.21 & $0.48^{*}$ & -0.23 & 0.03 & -0.17 & -0.04 & -0.07 & 0.04 & & \\
\hline TP & 0.05 & 0.23 & 0.06 & -0.06 & 0.07 & 0.1 & -0.36 & -0.06 & 0.06 & 0.2 & 0.05 & 0.11 & -0.11 & \\
\hline E. coli & -0.07 & 0.08 & -0.12 & 0.2 & 0.3 & 0.02 & -0.09 & -0.34 & -0.21 & -0.07 & 0.13 & 0.01 & -0.1 & -0.06 \\
\hline & & & & & & & $\mathrm{P} 2$ & & & & & & & \\
\hline TSS & $-0.43^{\star}$ & & & & & & & & & & & & & \\
\hline Cond & $0.62^{\star \star *}$ & -0.2 & & & & & & & & & & & & \\
\hline Tur & -0.16 & $0.43^{\star}$ & -0.26 & & & & & & & & & & & \\
\hline DO & 0.27 & -0.05 & 0.12 & -0.22 & & & & & & & & & & \\
\hline $\mathrm{OC}$ & -0.16 & 0.26 & -0.05 & $0.57^{* *}$ & -0.34 & & & & & & & & & \\
\hline COD & -0.1 & 0.12 & -0.24 & 0.24 & -0.12 & 0.37 & & & & & & & & \\
\hline BOD & -0.07 & 0.04 & -0.1 & -0.03 & -0.15 & 0.05 & 0.15 & & & & & & & \\
\hline $\mathrm{NH}_{4}$ & -0.01 & 0.4 & -0.04 & $0.56^{\star \star}$ & 0.34 & 0.35 & 0.24 & 0.19 & & & & & & \\
\hline $\mathrm{NO}_{2}$ & -0.09 & 0.24 & -0.18 & $0.52^{* *}$ & -0.16 & $0.52^{\star *}$ & $0.44^{*}$ & 0.16 & $0.60^{* *}$ & & & & & \\
\hline $\mathrm{NO}_{3}$ & -0.1 & 0.39 & -0.23 & $0.68^{* *}$ & -0.19 & $0.65^{\star *}$ & 0.41 & 0 & $0.62^{* *}$ & $0.91^{\star *}$ & & & & \\
\hline TN & 0.17 & 0.19 & 0.12 & 0.36 & -0.11 & 0.34 & 0.22 & 0.1 & $0.49 *$ & $0.65^{\star \star *}$ & $0.65^{\star *}$ & & & \\
\hline $\mathrm{PO}_{4}$ & 0.01 & 0.25 & -0.04 & -0.04 & 0.31 & -0.18 & -0.21 & -0.14 & 0.03 & 0.18 & 0.1 & -0.03 & & \\
\hline TP & -0.08 & $0.59 * \star$ & -0.12 & $0.80^{\star \star}$ & 0.02 & $0.53^{\star \star}$ & 0.15 & -0.04 & $0.74^{\star \star}$ & $0.49 *$ & $0.64^{\star \star}$ & 0.4 & 0.06 & \\
\hline E. coli & -0.24 & 0.16 & -0.13 & $0.44^{\star}$ & -0.17 & 0.19 & 0.17 & -0.02 & 0.11 & 0 & 0.13 & 0.19 & 0.08 & 0.24 \\
\hline
\end{tabular}


Continued from Table 2

\begin{tabular}{|c|c|c|c|c|c|c|c|c|c|c|c|c|c|c|}
\hline & $\mathrm{pH}$ & TSS & Cond & Tur & DO & OC & COD & BOD & $\mathrm{NH}_{4}$ & $\mathrm{NO}_{2}$ & $\mathrm{NO}_{3}$ & TN & $\mathrm{PO}_{4}$ & TP \\
\hline & & & & & & & P3 & & & & & & & \\
\hline TSS & -0.08 & & & & & & & & & & & & & \\
\hline Cond & -0.16 & -0.1 & & & & & & & & & & & & \\
\hline Tur & -0.07 & 0.3 & 0.14 & & & & & & & & & & & \\
\hline DO & 0.16 & -0.17 & -0.27 & $-0.51^{* *}$ & & & & & & & & & & \\
\hline OC & $-0.37^{\star}$ & 0.11 & 0.27 & $0.37^{\star}$ & -0.3 & & & & & & & & & \\
\hline COD & -0.01 & 0.16 & -0.23 & -0.06 & 0.09 & -0.02 & & & & & & & & \\
\hline BOD & -0.04 & 0.02 & -0.1 & 0.1 & $0.39^{*}$ & -0.01 & 0.08 & & & & & & & \\
\hline $\mathrm{NH}_{4}$ & 0.04 & 0.02 & 0 & -0.18 & 0.22 & 0.13 & 0.19 & 0.12 & & & & & & \\
\hline $\mathrm{NO}_{2}$ & 0.07 & $0.36^{\star}$ & -0.21 & $0.33^{\star}$ & -0.03 & -0.02 & $0.66^{\star \star}$ & 0.23 & $0.40^{\star \star}$ & & & & & \\
\hline $\mathrm{NO}_{3}$ & -0.05 & 0.24 & -0.07 & $0.61^{* *}$ & $-0.42^{\star *}$ & 0.24 & 0.3 & -0.05 & 0.12 & $0.72^{* *}$ & & & & \\
\hline TN & 0.11 & 0.21 & 0.14 & $0.66^{* *}$ & $-0.33^{*}$ & 0.3 & -0.02 & 0.06 & 0.24 & $0.42^{* *}$ & $0.56^{* *}$ & & & \\
\hline $\mathrm{PO}_{4}$ & -0.11 & $0.35^{\star}$ & 0.08 & 0.24 & 0.17 & 0.13 & -0.07 & $0.43^{\star *}$ & -0.08 & 0.04 & 0.05 & 0.07 & & \\
\hline TP & -0.2 & 0.05 & -0.1 & 0.32 & -0.11 & $0.40^{*}$ & 0.05 & 0.15 & $0.40^{* *}$ & 0.32 & 0.22 & $0.45^{\star \star}$ & -0.03 & \\
\hline E.coli & -0.28 & 0.04 & $0.33^{*}$ & $0.45^{\star \star}$ & $-0.53^{* *}$ & $0.78^{*}$ & 0 & -0.06 & -0.08 & 0.01 & $0.44^{\star \star}$ & 0.29 & 0.09 & 0.16 \\
\hline
\end{tabular}

\begin{tabular}{|c|c|c|c|c|c|c|c|c|c|c|c|c|c|c|}
\hline TSS & -0.12 & & & & & & & & & & & & & \\
\hline Cond & $0.48^{\star}$ & 0.1 & & & & & & & & & & & & \\
\hline Tur & -0.07 & $0.68^{* *}$ & 0.2 & & & & & & & & & & & \\
\hline DO & 0.17 & 0.09 & 0.39 & -0.07 & & & & & & & & & & \\
\hline OC & -0.22 & $0.43^{*}$ & -0.12 & $0.60^{\star *}$ & -0.08 & & & & & & & & & \\
\hline COD & -0.05 & 0.38 & 0 & $0.50^{* *}$ & -0.06 & $0.63^{* *}$ & & & & & & & & \\
\hline BOD & 0.03 & 0.27 & 0.11 & 0.18 & -0.18 & 0.26 & 0.04 & & & & & & & \\
\hline $\mathrm{NH}_{4}$ & -0.18 & 0.01 & 0.16 & 0.15 & 0.19 & 0.19 & 0.13 & -0.05 & & & & & & \\
\hline $\mathrm{NO}_{2}$ & -0.16 & 0.39 & 0.27 & $0.73^{* *}$ & -0.32 & $0.55^{\star *}$ & $0.44^{*}$ & 0.26 & 0.34 & & & & & \\
\hline $\mathrm{NO}_{3}$ & -0.22 & 0.04 & 0.18 & 0.38 & -0.38 & 0.25 & 0.28 & -0.07 & 0.17 & $0.79 * *$ & & & & \\
\hline TN & -0.09 & $0.43^{\star \star}$ & $0.48^{*}$ & 0.21 & 0.13 & 0.19 & -0.01 & 0.29 & 0.3 & $0.53^{\star \star}$ & $0.44^{\star}$ & & & \\
\hline $\mathrm{PO}_{4}$ & 0.07 & $0.50^{* *}$ & 0.26 & $0.87^{* *}$ & -0.18 & $0.47^{*}$ & $0.55^{* *}$ & 0.09 & 0.17 & $0.73^{* *}$ & $0.51^{* *}$ & 0.19 & & \\
\hline TP & -0.08 & $0.68^{*}$ & 0.17 & $0.96^{* *}$ & -0.08 & $0.67^{* *}$ & $0.51^{* *}$ & 0.2 & 0.2 & $0.76^{* *}$ & 0.37 & 0.28 & $0.80^{* *}$ & \\
\hline E.coli & -0.14 & $0.56^{\star}$ & -0.02 & $0.86^{\star \star}$ & -0.03 & $0.66^{\star \star}$ & 0.41 & 0.16 & 0.02 & $0.50^{* \star}$ & 0.19 & 0.04 & $0.68 * \star$ & $0.86^{\star \star}$ \\
\hline
\end{tabular}

\begin{tabular}{|c|c|c|c|c|c|c|c|c|c|c|c|c|c|c|}
\hline TSS & 0.05 & & & & & & & & & & & & & \\
\hline Cond & 0.23 & -0.25 & & & & & & & & & & & & \\
\hline Tur & -0.03 & $0.54^{* *}$ & -0.03 & & & & & & & & & & & \\
\hline DO & 0.3 & -0.29 & 0.26 & -0.19 & & & & & & & & & & \\
\hline OC & 0.1 & 0.23 & 0.17 & $0.62^{* *}$ & -0.27 & & & & & & & & & \\
\hline COD & 0.12 & 0.3 & -0.14 & 0.26 & $-0.43^{*}$ & $0.41^{*}$ & & & & & & & & \\
\hline BOD & 0.01 & 0.35 & -0.39 & -0.03 & -0.37 & 0.04 & 0.33 & & & & & & & \\
\hline $\mathrm{NH}_{4}$ & 0.01 & 0.19 & 0.07 & 0.11 & 0.04 & 0.05 & 0.31 & 0.22 & & & & & & \\
\hline $\mathrm{NO}_{2}$ & 0.01 & 0.24 & -0.22 & 0.07 & -0.3 & 0.14 & 0.3 & 0.02 & -0.05 & & & & & \\
\hline $\mathrm{NO}_{3}$ & -0.03 & 0.33 & -0.11 & $0.46^{\star}$ & -0.4 & 0.34 & $0.48^{\star}$ & 0.04 & 0.13 & $0.52^{\star \star}$ & & & & \\
\hline TN & 0.02 & 0.37 & 0.12 & $0.46^{\star}$ & -0.22 & 0.27 & $0.53^{\star *}$ & 0 & $0.53^{\star \star}$ & 0.34 & $0.75^{\star \star}$ & & & \\
\hline $\mathrm{PO}_{4}$ & 0.34 & 0.36 & 0.1 & 0.05 & -0.35 & 0.17 & 0.33 & $0.48^{*}$ & -0.03 & 0.18 & 0.22 & 0.2 & & \\
\hline TP & -0.05 & $0.44^{\star}$ & -0.12 & $0.77^{\star \star \star}$ & -0.04 & 0.4 & $0.42^{\star}$ & 0.1 & $0.41^{*}$ & 0.05 & $0.43^{*}$ & $0.54^{\star \star}$ & -0.02 & \\
\hline E.coli & -0.05 & $0.53^{\star \star}$ & -0.01 & $0.93^{* *}$ & -0.06 & $0.56^{\star \star \star}$ & 0.15 & -0.06 & 0.14 & 0.02 & 0.25 & 0.41 & -0.03 & $0.72^{\star *}$ \\
\hline
\end{tabular}

\begin{tabular}{|c|c|c|c|c|c|c|c|c|c|c|c|c|c|c|}
\hline & & & & & & & $\frac{0.10}{P 6}$ & 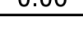 & & 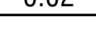 & & 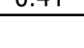 & & \\
\hline pH & -0.05 & & & & & & & & & & & & & \\
\hline TSS & -0.16 & -0.21 & & & & & & & & & & & & \\
\hline Cond & 0.13 & -0.05 & -0.05 & & & & & & & & & & & \\
\hline Tur & 0.14 & 0.32 & 0.32 & 0.28 & & & & & & & & & & \\
\hline DO & 0.06 & $-0.46^{\star}$ & $0.50 *$ & 0.04 & -0.03 & & & & & & & & & \\
\hline$O C$ & -0.28 & 0 & -0.03 & 0.09 & 0.04 & -0.15 & & & & & & & & \\
\hline COD & -0.34 & 0.16 & -0.12 & 0.31 & -0.24 & 0.06 & 0.33 & & & & & & & \\
\hline $\mathrm{NH}_{4}$ & -0.03 & 0.24 & 0.27 & -0.06 & 0.04 & 0.24 & 0.27 & 0.2 & & & & & & \\
\hline $\mathrm{NO}_{2}$ & -0.27 & $0.53^{* *}$ & -0.08 & -0.04 & -0.3 & 0.25 & $0.42^{\star}$ & 0.18 & $0.60^{* \star}$ & & & & & \\
\hline $\mathrm{NO}_{3}$ & -0.31 & $0.48^{*}$ & 0.03 & -0.08 & -0.32 & $0.48^{*}$ & 0.22 & 0.04 & 0.34 & $0.72^{\star \star}$ & & & & \\
\hline TN & -0.06 & 0.2 & $0.48^{*}$ & 0.03 & 0.25 & $0.53^{\text {** }}$ & 0.05 & -0.15 & $0.49^{*}$ & 0.33 & $0.64^{* *}$ & & & \\
\hline $\mathrm{PO}_{4}$ & 0.08 & -0.14 & -0.11 & 0.26 & 0.03 & -0.07 & -0.04 & -0.09 & -0.09 & $0.43^{*}$ & -0.1 & -0.25 & & \\
\hline TP & -0.02 & 0.06 & -0.14 & 0.05 & -0.22 & -0.01 & 0.02 & -0.14 & 0.31 & 0.3 & 0.06 & -0.11 & $0.70^{\star \star *}$ & \\
\hline E.coli & -0.06 & 0.01 & 0.01 & 0.06 & 0.35 & 0.27 & -0.16 & -0.24 & -0.08 & -0.07 & 0.19 & 0.3 & -0.05 & -0.14 \\
\hline
\end{tabular}

P1 - Spring in the Atlantic Forest; P2 - Culvert in the mean course of the principal tributary under the road adjacent to the rural area; P3 - Culvert under State Highway AMG-3085 in the grazing area of the Burros stream in the reservoir; P4 - Culvert under Highway AMG-3085 in pasture area of the Grama stream; P5 - Outlet of the Vista Alegre stream in the rural area and P6 - Catchment to the Water Treatment Station (see Figure 2)

from the decomposition of forest material, presenting significant correlation with nitrate $(\mathrm{p}<0.01)$ and with ammonium $(\mathrm{p}<0.05)$, demonstrating the decomposition of this material and the possibility of nitrification occurring, corroborated by the correlation of TN with pH. Silva et al. (2007) state that a high concentration of organic material in decomposition increases the amount of dissociated ions in the water, which results in an increase in electrical conductivity, justifying 
A.

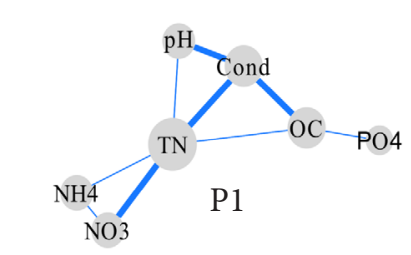

C.
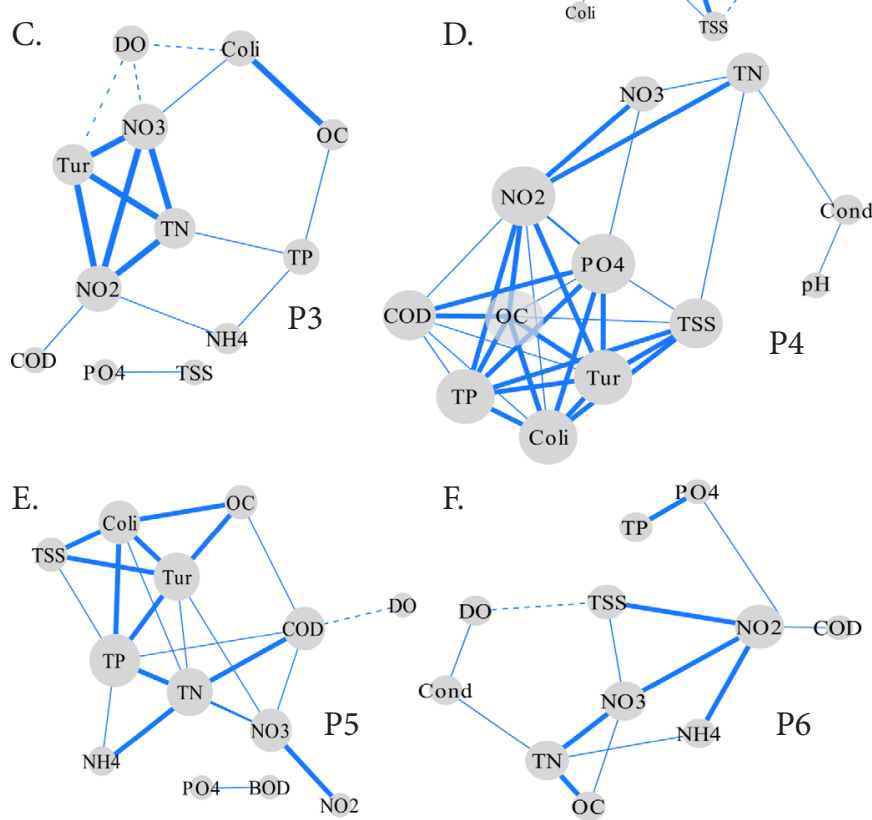

P1 - Spring in the Atlantic Forest; P2 - Culvert in the mean course of the principal tributary under the in road adjacent to the rural area; P3 - Culvert under State Highway AMG-3085 in the grazing area of the Burros stream in the reservoir; P4 - Culvert under Highway AMG-3085 in pasture area of the Grama stream; P5 - Outlet of the Vista Alegre stream in the rural area and P6 - Catchment to the Water Treatment Station

Figure 3. Correlations among the water quality variables at the six sampling sites $(\mathrm{P} 1, \ldots, \mathrm{P} 6)$

the TN correlation with electrical conductivity due to the decomposition of the organic material. Electrical conductivity also had correlations with $\mathrm{pH}$ and OC. The correlation of OC with TN confirms that the organic material at the site was of plant origin, thus the correlation of these variables with $\mathrm{PO}_{4}^{3-}$ is associated to primary production at the source.

P2 is situated in a double tubular spring concrete culvert under the road adjacent to the middle course of the Burros stream. In its surroundings, the predominant classes are pasture $(55 \%)$, forest $(20.3 \%)$ and wetland $(12.4 \%)$, with only $1.7 \%$ constructed area. The strong correlations between $\mathrm{NO}_{3}{ }^{-}$, TN and turbidity (Figure $3 \mathrm{~B}$ ) suggest the surface runoff transports organic material, such as feces of animal origin and plant material, to the stream, reinforced by the absence of the Riparian Forest. This is corroborated by the moderate correlations with the $\mathrm{NH}_{4}{ }^{+}$and the TP, which have a strong correlation with the TSS.

It was again verified the nitrogen cycle as a central part of the limnological dynamics of the site, but with a different origin. $\mathrm{TN}$, ammonium, nitrite and nitrate were correlated with the organic material of the site (correlation with COD and OC), which also demonstrates that the $\mathrm{NO}_{3}^{-}$source is correlated with the turbidity, reinforcing this analysis. Turbidity is related with the TSS and with the E.coli, reaffirming the origin of the contamination from animal feces (principally from livestock) carried by surface runoff (Muirhead et al., 2005). TSS has a negative correlation with $\mathrm{pH}$, which is positively correlated with the conductivity, suggesting chemical changes in the water course resulting from solids carried by the drainage process of the adjacent soils, with Red-yellow Latosol with acidic characteristics predominating in this section (EMBRAPA, 2015).

P3 corresponds to the outlet of the Burros stream in the Dr. João Penido reservoir, being the tributary that most contributes (greatest flow) to the reservoir (Figure 2). P2 is a point located at a cellular concrete culvert under a paved road that has undergone various modifications, such as vegetation suppression, slope cutting and land movement due to the construction of the state highway (AMG-3085) connecting to the regional airport.

According to Figure 2, the predominant land use types in the P3 drainage area are pasture (53\%) and wetland (15\%) with predominance of the Typha domingensis sp., and forest (17\%). Figure 3C shows various forms of nitrogen with correlations of 0.01 significance: $\mathrm{TN}, \mathrm{NO}_{2}$ and $\mathrm{NO}_{3}^{-}$, which resulted from surface runoff.

The presence of organic material was from domestic sewage and agricultural fertilizer runoff from the pastures. This explains the strong correlation of these nutrients with turbidity, in addition to the moderate correlations with COD, $\mathrm{NH}_{4}^{+}$, TP and E.coli. This last parameter has a strong correlation with OC and negative correlation with DO, justified by the oxygen consumption for the oxidation of the organic material, diminishing its availability in the water. In isolation, the orthophosphate and the TSS have a correlation with 0.05 significance due to the runoff of allochthonous material from the pastures, suggesting the use of fertilizers.

$\mathrm{P} 4$ is also located at a culvert under the AMG-3085 highway and was the section that was most disrupted during the construction of the state highway, with much land movement and deviation of its course (Figure 2).

The predominant classes in the subbasin are pasture $(73 \%)$ and urbanization and wetland (5\% each). The presence of the highway, the pasture on very flat topography and rural property with bovine herds in the vicinity of P4 explains the correlations between the highlighted parameters for OC that strongly correlate with $\mathrm{NO}_{2}, \mathrm{COD}, \mathrm{TP}$, E.coli and turbidity; and moderately with $\mathrm{PO}_{4}^{3-}$ and TSS (Figure 3D). The availability of nutrients favors the proliferation of macrophytes of the type Salvinia sp. observed in this section. The strong correlations between the nitrogen variations $\mathrm{NO}_{2}, \mathrm{NO}_{3}{ }^{-}$and $\mathrm{TN}$ corroborate the previous analysis, again with the nitrogen cycle, for example by nitrification-denitrification processes. The correlations at 0.05 significance level between TN, electrical conductivity and $\mathrm{pH}$ show that the waters of this stream are chemically altered because of runoff from the pastures, erosion on the slopes and the road itself.

P5 is situated on a wood bridge under an unpaved road from the rural housing at the outlet of the Vista Alegre stream in the reservoir. The predominant class in the subbasin is pasture, which comprises $58 \%$ of the area (Figure 2). This is a lowland region with predominance of Typha domingensis sp., in addition to some residential homes in the proximity.

According to Figure 3E, the strong correlations between turbidity, TP, TSS, E.coli and OC show that there is a point 
source supply of organic material from the rural houses, which is an environment without sewage treatment that discharges wastewater directly into the stream, along with the animal feces and fertilizers carried from the pastures. This justifies the correlations with 0.01 and 0.05 significance of the nitrogen cycle elements $\mathrm{NH}_{4}^{+}, \mathrm{NO}_{2}^{-}, \mathrm{NO}_{3}^{-}$and $\mathrm{TN}$, with the TP and the COD showing the oxygen consumption for the oxidation of the organic material, confirmed through the negative correlation with DO. In addition to justifying the moderate correlation isolated from the orthophosphate with the $\mathrm{DBO}_{5.20}$, the presence of these variables points to undesirable hygienicsanitary conditions, emphasizing that the continuous ingestion of waters with nitrite and nitrate induces methemoglobinemia and the potential formation of carcinogenic nitrosamines and nitrosamides (Alaburda \& Nishihara, 1998).

The nitrogen cycle stood out from P2 to P5 (Figures 3B, C, $\mathrm{D}$ and $\mathrm{E}$ ), with a different behavior at the spring. The supply of macronutrients from the pastures has been confirmed by other authors (Li et al., 2012; Park et al., 2014) and was observed in almost all sections of the CBJPR. Near to the wastewater launch site the incorporation of macronutrients was greater compared to more distant localities. This was verified in the water samples collected. Buck et al. (2004) analysed these effects of scale nearest (local) and more distant (basin) in rivers of New Zealand and concluded that the effects of soil use on water quality vary with the order of the stream.

Valente et al. (1997) argue that OC and the COD have similar chemical behavior due to the need for oxidation of all organic material. In a general manner, OC was highlighted because it had correlations with more variables (20) than COD (14). It is the key parameter in the section 4 (P4). The exception is $\mathrm{P} 5$, where COD had more correlations (5) than OC (3), due to the presence of a rural community without sewage treatment. $\mathrm{OC}$ is a parameter that has been linked to the input of plant material while COD is connected to domestic sewage, due to absence of industries in this basin.

In the catchment of the reservoir, P6, erosion was observed along the banks, which was also described by Bucci \& Oliveira (2014) and Bucci et al. (2015). According to Figure 3F, the nutrients $\mathrm{NH}_{4}^{+}, \mathrm{NO}_{2}{ }^{-}, \mathrm{NO}_{3}^{-}, \mathrm{TN}, \mathrm{TSS}$ and $\mathrm{OC}$ had correlations with 0.01 significance while conductivity, $\mathrm{COD}, \mathrm{PO}_{4}{ }^{3-}$ and $\mathrm{TP}$ had correlations with 0.05 significance. This shows that the runoff was carrying nutrients from the pastures, sewage from the residences close to the catchment and erosion at the banks, which accelerates the biogeochemical degradation processes of the organic material and reduces oxygen availability, which was confirmed by the negative correlation between TSS and DO. Rocha et al. (2014) and Rocha \& Pereira (2016) concluded that the runoff and organic contribution synthesize the current processes in a negative way in the catchment of the Dr. João Penido reservoir. Despite the capacity for self-purification in this lentic environment, the anthropogenic occupation of the banks combined with suppression of vegetation in the permanent preservation areas (PPA), the raising of livestock and the absence of sewage treatment compromises the water quality in this section.

It is noteworthy that the great majority of the correlations are positive between the water quality variables at all sampled points. The nitrate, nitrite and ammonium, TN, FT, $\mathrm{PO}_{4}^{3-}$, TSS, turbidity, $\mathrm{DBO}_{5.20}, \mathrm{COD}, \mathrm{OC}$ and E.coli are parameters for which an increase signifies a reduction in water quality, which is portrayed in some water quality index (WQI) of agencies like CETESB (2018) and in the water framework classes of Resolution CONAMA 357/2005 (Brasil, 2005).

In turn, the DO, was the only parameter that had more than one negative correlation: at P3, it was negatively correlated with turbidity, nitrate and E.coli; at P5, it was negatively influenced by the COD; and at P6, by the TSS. DO is a fundamental parameter for the aquatic life and an environment with low dissolved oxygen can be considered polluted.

\section{Conclusions}

1. The correlation charts make a simpler and more didactic way to represent the correlations between the limnological variables.

2. The oxidation processes for the decomposition of organic material were evident in all the monitored sections, including at the spring.

\section{Literature Cited}

Alaburda, J.; Nishihara, L. Presença de compostos de nitrogênio em águas de poço. Revista de Saúde Pública, v.32, p.531-537, 1998. https://doi.org/10.1590/S0034-89101998000200009

ANA - Agência Nacional de Águas. Guia nacional de coleta e preservação de amostras: Água, sedimento, comunidades aquáticas e efluentes líquidos. Brasília: ANA, 2011.325p.

APHA - American Public Health Association. Standard methods for the examination of water and wastewater. 22.ed. Washington: APHA, 2012. 1404p.

Azhar, S. C.; Aris, A. Z.; Yusoff, M. K.; Ramli, M. F.; Juahir, H. Classification of river water quality using multivariate analysis. Procedia Environmental Sciences, v.30, p.79-84, 2015. https://doi. org/10.1016/j.proenv.2015.10.014

Bailly, D.; Fernandes, C. A.; Silva, V. F. B.; Kashiwaqui, E. A. L.; Damásio, J. F.; Wolf, M. J.; Rodrigues, M. C. Diagnóstico ambiental e impactos sobre a vegetação ciliar da microbacia do córrego da ponte, área de proteção ambiental do rio Iguatemi, MS. Revista em Agronegócios e Meio Ambiente, v.5, p.409-427, 2012.

Brasil. Ministério do Meio Ambiente. Resolução CONAMA No 357 de março de 2005. Brasília: Diário Oficial da União, 2005. 27p.

$\mathrm{Bu}, \mathrm{H}$.; Meng, W.; Zhang, Y.; Wan, J. Relationships between land use patterns and water quality in the Taizi River basin, China. Ecological Indicators, v.41, p.187-197, 2014. https://doi. org/10.1016/j.ecolind.2014.02.003

Bucci, M. M. H. S.; Delgado, F. E. da F.; Oliveira, L. F. C. de. Water quality and trophic state of a tropical urban reservoir for drinking water supply (Juiz de Fora, Brazil). Lake and Reservoir Management, v.31, p.134-144, 2015. https://doi.org/10.1080/104 02381.2015.1029151

Bucci, M. M. H. S.; Oliveira, L. F. C. de. Índices de qualidade da água e de estado trófico na represa Dr. João Penido (Juiz de Fora, MG). Revista Ambiente e Água, v.9, p.130-148, 2014.

Buck, O.; Niyogi, D. K.; Townsend, C. R. Scale-dependence of land use effects on water quality of streams in agricultural catchments. Environmental Pollution, v.130, p.287-299, 2004. https://doi. 
org/10.1016/j.envpol.2003.10.018

CCME - Canadian Council of Ministers of the Environment. Water quality index: Technical report. Winnipeg: Canadian Water Quality Guidelines for the Protection of Aquatic Life, 2001. 13p.

CESAMA - Companhia de Saneamento Municipal de Juiz de Fora. Mananciais: Represa Dr. João Penido. 2014. Available on: <http:// www.cesama.com.br/?pagina=hidrografia $>$. Accessed on: Nov. 2018.

CETESB - Companhia de Tecnologia de Saneamento Ambiental do Estado de São Paulo. Apêndice D: Índice de qualidade das águas 2017. São Paulo: CETESB, 2018. 34p.

EMBRAPA - Empresa Brasileira de Pesquisa Agropecuária. Latossolos. 2015. Available on: <http://www.agencia.cnptia.embrapa.br/ Agencia16/AG01/arvore/AG01_96_10112005101956.html>. Accessed on: Nov. 2018.

Jacomy, M.; Venturini, T.; Heymann, S.; Bastian, M. ForceAtlas2, a continuous graph layout algorithm for handy network visualization designed for the Gephi software. Plos One, v.9, p.112, 2014. https://doi.org/10.1371/journal.pone.0098679

Kobourov, S. G. Spring embedders and force directed graph drawing algorithms. Ithaca: Cornell University, 2012. 23p.

Li, Y. L.; Liu, K.; Li, L.; Xu, Z. X. Relationship of land use/cover on water quality in the Liao River basin, China. Procedia Environmental Sciences, v.13, p.1484-1493, 2012. https://doi. org/10.1016/j.proenv.2012.01.140

Macedo, J. A. B. de. Métodos laboratoriais de análises físico-químicas e microbiológicas. 3.ed. Belo Horizonte: Conselho Regional de Química de Minas Gerais, 2005.601p.

Moraes, I. C.; Conceição, F. T. da; Cunha, C. M. L. da; Moruzzi, R. B. Comparação de metodologias na definição de fluxos acumulados a partir de modelos digitais de elevação do terreno aplicado a suscetibilidade de inundações. Revista Brasileira de Recursos Hídricos, v.19, p.223-235, 2014. https://doi.org/10.21168/rbrh.v19n2.p223-235

Muirhead, R. W.; Collins, R. P.; Bremer, P. J. Erosion and subsequent transport state of Escherichia coli from cowpats. Applied and Environmental Microbiology, v.71, p.2875-2879, 2005. https:// doi.org/10.1128/AEM.71.6.2875-2879.2005

Park, Y. S.; Kwon, Y. S.; Hwang, S. J.; Park, S. Characterizing effects of landscape and morphometric factors on water quality of reservoirs using a self-organizing map. Environmental Modelling \& Software, v.55, p.214-221, 2014. https://doi.org/10.1016/j.envsoft.2014.01.031

Rocha, C. H. B.; Freitas, F. A.; Silva, T. M. da. Alterações em variáveis limnológicas de manancial de Juiz de Fora devido ao uso da terra. Revista Brasileira de Engenharia Agrícola e Ambiental, v.18, p.431436, 2014. https://doi.org/10.1590/S1415-43662014000400011

Rocha, C. H. B.; Pereira, A. M. Análise multivariada para seleção de parâmetros de monitoramento em manancial de Juiz de Fora, Minas Gerais. Revista Ambiente e Água, v.11, p.176-187, 2016.

Rocha, C. H. B.; Pereira, B. H. C.; Silva, A. F. R. da; Oliveira, M. de; Casquin, A. P.; Figueiredo, M. R. de. Land use impacts on water resources of the Manacás Lake Basin, Minas Gerais, Brazil. Revista Ambiente e Água, v.11, p.929-942, 2016.

Silva, D. M. L. da; Ometto, J. P. H. B.; Lobo, G. de A.; Lima, W. de P.; Scaranello, M. A.; Mazzi, E.; Rocha, H. da R. Can land use changes alter carbon, nitrogen and major ion transport in subtropical Brazilian streams? Scientia Agricola, v.64, p.317-324, 2007. https:// doi.org/10.1590/S0103-90162007000400002

Trindade, A. L. C.; Almeida, K. C. de B.; Barbosa, P. E.; Oliveira, S. M. A. C. Tendências temporais e espaciais da qualidade das águas superficiais da sub-bacia do Rio das Velhas, estado de Minas Gerais. Engenharia Sanitária e Ambiental, v.22, p.13-24, 2017. https://doi.org/10.1590/s1413-41522016131457

Valente, J. P. S.; Padilha, P. M.; Silva, A. M. M. Oxigênio dissolvido (OD), demanda bioquímica de oxigênio (DBO) e demanda química de oxigênio (DQO) como parâmetros de poluição no ribeirão Lavapés/Botucatu - SP. Eclética Química, v.22, p.49-66, 1997. https://doi.org/10.1590/S0100-46701997000100005

Vasco, A. N. do; Britto, F. B.; Pereira, A. P. S.; Méllo Júnior, A. V.; Garcia, C. A. B.; Nogueira, L. C. Avaliação espacial e temporal da qualidade da água na sub-bacia do rio Poxim, Sergipe, Brasil. Revista Ambiente e Água, v.6, p.118-130, 2011. https://doi. org/10.4136/ambi-agua.178

WFD - Water Framework Directive. Directive 2000/60/EC of the European parliament and of the council establishing a framework for community action in the field of water policy. 2000. 72p. Available on: < https://eur-lex.europa. eu/resource.html? uri=cellar:5c835afb-2ec6-4577-bdf8756d3d694eeb.0004.02/DOC_1\&format=PDF>. Accessed on: Nov. 2018. 